\title{
Conservation of declining migratory animals: An interdisciplinary analysis of biology, sociology, and policy
}

\author{
Anurag A. Agrawal ${ }^{1,2^{*}}$, Sonia Altizer ${ }^{3}$, David Hunter ${ }^{4}$, Peter P. Marra ${ }^{5}$, Steven A. Wolf ${ }^{6,2}$ \\ ${ }^{1}$ Department of Ecology and Evolutionary Biology \\ Cornell University, Ithaca, NY 14853, USA (agrawal@cornell.edu) \\ *correspondence, 607-280-6832 \\ ${ }^{2}$ Atkinson Center for a Sustainable Future \\ Cornell University, Ithaca, NY 14853, USA \\ ${ }^{3}$ Odum School of Ecology \\ University of Georgia, Athens, GA 30602, USA (saltizer@uga.edu) \\ ${ }^{4}$ American University Washington College of Law, 4801 Massachusetts Avenue NW, \\ Washington, D.C. 20016, USA (dhunter@wcl.american.edu) \\ ${ }^{5}$ Migratory Bird Center, Smithsonian Conservation Biology Institute, National Zoological Park \\ PO Box 37012 MRC 5503, Washington, DC 20013, USA (marrap@si.edu) \\ ${ }^{6}$ Department of Natural Resources \\ Cornell University, Ithaca, NY 14853, USA (saw44@cornell.edu)
}

Citation: Agrawal, A.A., S. Altizer, D. Hunter, P.P. Marra, and S.A. Wolf. Conservation of declining migratory animals: An interdisciplinary analysis of biology, sociology, and policy. OSF Preprints (https://osf.io/preprints/).

Key words: International environmental policy, Migratory Bird Treaty, Migratory connectivity, Monarch butterfly Danaus plexippus, Population decline, Seasonal interactions

Acknowledgments: This work was supported by Cornell University's Atkinson Center for a Sustainable Future. We thank Debal Ray for discussion, Amy Scarpignato for help in developing Figure 1, and Hidetoshi Inamine for producing Figure 4. 


\begin{abstract}
Migratory animals are imperiled worldwide. Because they cross geopolitical boundaries and rely on diverse habitats and resources, conserving migratory populations presents many challenges. We assess conservation policy for migratory animals and identify multiple scales at which analysis and action are needed: 1) local-and landscape-scale conservation policy based on the movement and habitat requirements of species, 2) targeted mitigation of anthropogenic stressors that impact multiple species and contribute to regional environmental degradation, and 3) a critical dialog about the role of societal economic growth and material consumption on the grand conservation challenges. Our arguments are illustrated through the case of monarch butterflies and generalized to diverse migratory animals. To be effective, international law and policy efforts must be binding within countries, address broad-scale drivers of environmental degradation, and target interventions based on developments in the science of migratory connectivity that span periods of breeding, migration, and overwintering.
\end{abstract}

\title{
Introduction
}

Having celebrated the $100^{\text {th }}$ year anniversary of the Migratory Bird Treaty, it is important to recognize successes in conserving flagship migratory species, including gray whales and bald eagles. At the same time, society must confront the remarkable global convergence of migratory species declines, from ungulates and fish, to birds, bats and butterflies (Harris et al. 2009, Bowlin et al. 2010) (Figure 1). In response to habitat loss, food subsidy, barriers to movement, and climate change, some migrations have disappeared altogether (Wilcove and Wikelski 2008), and others have shifted in timing, distances, and routes travelled (e.g., Visser et al. 2009, Pulido and Berthold 2010). The loss of migratory animals and their spectacular international movements reduces ecosystem function and diminishes the values humans derive from nature (Bauer and Hoye 2014). Their loss is also part of a class of complex, large-scale, multi-jurisdictional environmental problems the global community must address to advance biodiversity conservation (Leadley et al. 2014).

By definition, migratory animals have geographically distinct breeding and non-breeding phases that are connected by long-distance migrations. A key issue for migratory species is their tendency to migrate and breed (or overwinter) in large numbers, with high abundances needed to successfully navigate and avoid predators (Wilcove and Wikelski 2008). At the same time, their widespread annual ranges make migratory species highly susceptible to multiple biotic and abiotic stresses, including shifting patterns of resource exploitation by humans (Webster et al. 2002). To succeed in protecting migratory species, scientists, conservation practitioners and policy makers must develop trans-boundary solutions and engage in international cooperation to fill knowledge gaps and overcome institutional barriers to conservation.

Although each animal migration is unique, there are common biological and social threads. Here we identify three levels of analysis and action necessary to reverse migratory species declines: (i) expand the science of migratory connectivity to identify the times and locations where individual species are most vulnerable, (ii) address how multiple anthropogenic stressors, including land use change, pesticide application, and the proliferation of invasive species are impacting animal migrations and their population sustainability, and (iii) recognize 
Figure 1. Crossing boundaries in animal migration (Figure 1). In the four panels depicted here, individual animals make their annual (or longer) round-trip journey. a) The likely nocturnal migration routes of Bogong moths (Agrotis infusa), a generalist noctuid, in Australia. In spring (September - November) moths move from Queensland, New South Wales and Victoria, to caves in the Australian Alps (December - February). The moths leave the caves at the end of the summer and remigrate (March - April) along similar routes as in spring to their breeding grounds (May - August). Migration journeys have been confirmed with vertical radar, long-term light trapping and careful observation (Warrant et al. 2016).

b) Mature Atlantic bluefin tuna (Thunnus thynnus) undergo two types of migrations: a foraging migration to the North Atlantic Ocean and a transAtlantic migration to spawning areas in the Mediterranean Sea. Movements of this single individual were documented with implanted archival light-level geolocators that provide light-level data to estimate geographic position and sea surface temperature to help improve latitude estimates.

c) Leatherback sea turtles (Dermochelys coriacea) travel great distances between nesting and feeding grounds. The path of an individual of the western Pacific population travels from nesting sites in Indonesia to foraging grounds in the western US and back to nesting sites upon reaching sexual maturity. Satellite tags attached to the carapace of the turtle transmit to Argos satellites when the animal is at or near the surface.

d) The classic migration of Wildebeest (Connochaetes taurinus) from the Serengeti in Tanzania to Kenya's Maasai Mara and back. In August, wildebeest migrate towards the Maasai Mara, where they remain until the rains begin in the southern Serengeti (November) and then migrate south. The herds remain in the southern Serengeti until April for calving season, then head norhwest to western and northern Serengeti (May July) (adapted from Musiega et al. 2006). Tracking has been conducted with a combination of radio transmitters followed with fixed-wing aircraft and satellite tags on collars.

Data for panels b and c were accessed from the U.S. Animal Telemetry Network Data Assembly Center. 2016

http://oceanview.pfeg.noaa.gov/ATN/\#. Basemap sources: Esri, DigitalGlobe, Earthstar Geographics, CNES/Airbus DS, GeoEye, USDA FSA, USGS, Getmapping, Aerogrid, IGN, IGP, and the GIS User Community.
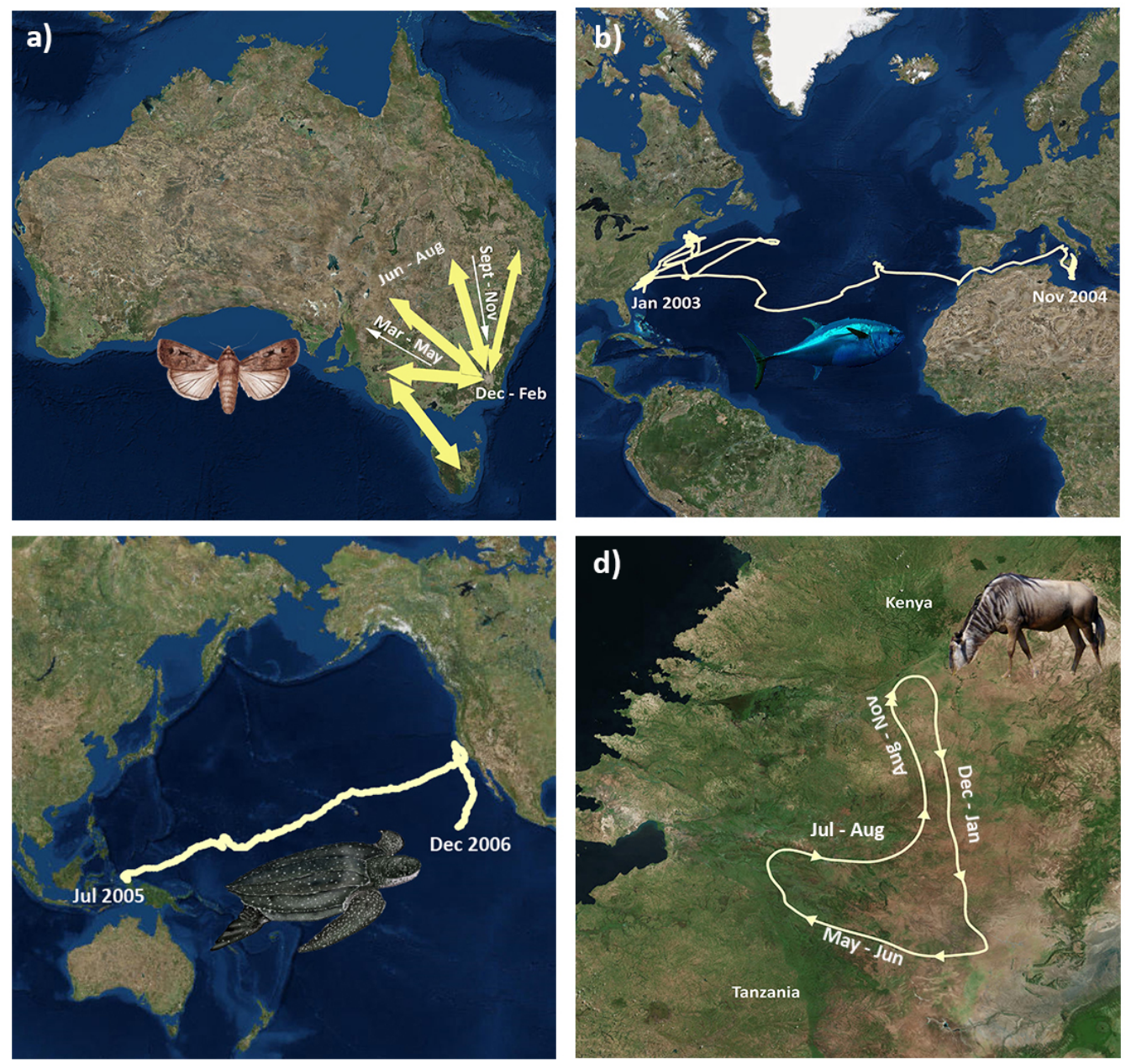
that, at the largest scale, material consumption is the ultimate driver of ecosystem degradation and the loss of migratory species. We review past international agreements and national policies targeting migratory species conservation, and we outline how future commitments should incorporate scientific understanding of declining species and also integrate socioeconomic and ecological impacts of interventions. We illustrate each of these points through the wellpublicized case of North American monarch butterflies. Specifically, we focus on scientific efforts to better understand their movement ecology and population threats, and on conservation initiatives to restore and protect their spectacular tri-national migration.

\section{The Science of Migratory Connectivity}

Knowledge of where animals go throughout their annual cycles, and at what points they are most vulnerable to environmental change (Bowlin et al. 2010, Runge et al. 2014) is crucial to predict reproductive success and mortality rates of migratory species. Comprehensive ecological data on most animal migrations covering both breeding and non-breeding areas remain elusive, in part because many animals are difficult to follow, and data collection is challenging and expensive. As cases in point, migratory routes and ecologies are largely unknown for insects such as dragonflies and for nocturnal animals such as tree bats. Scientists have documented basic range distributions for most migratory species, but better information on the geographic links (termed migratory connectivity) and the demographic connections (termed seasonal interactions) between stages of a migratory animal's annual cycle (Webster et al. 2002) is crucially needed (Figure 2).

Anthropogenic forces, including climate warming and changes to resource distributions, have changed the timing and extent of many seasonal migrations (e.g. Fiedler 2003, Hurlbert and Liang 2012, Satterfield et al. 2018). Research on migratory connectivity and seasonal interactions can advance population models to explain and predict theses changes in migratory species abundance and distribution (Marra et al. 2015). For example, winter habitat quality can influence spring arrival date on the breeding grounds, which can in turn affect reproduction, including the number of successful broods and total young fledged, as has been demonstrated for American Redstarts (Norris et al. 2004). Similarly, changes in resources in breeding habitats or stopover sites can affect migratory success or winter survival. In some cases, the removal of physical barriers (e.g., dams, highways), or targeted habitat restoration, can help restore migratory populations, as demonstrated for Pacific salmon and other fish species (Meixler et al. 2009). In other cases, more expansive habitat modifications and the removal of threats across multiple stages of the migratory cycle are needed for populations to recover (e.g., Martin et al. 2007).

In fast-reproducing species like most insects, populations have the potential to recover from temporary reproductive failure or mass mortality through high fecundity and quick turnaround of multiple generations. Conversely, for most vertebrates, individuals typically make the annual migration one or more times before reproducing; thus failure to complete the cycle can have substantial impacts on population viability. For example, breeding failure in blacklegged kittiwakes altered schedules of migratory transitions and locations of overwintering (Bogdanova et al. 2011). Although the impacts of these shifts for population dynamics are unclear, the result underscores the reciprocal importance of population abundance for migratory success (Wilcove and Wikelski 2008). 
Figure 2. A conceptualization of the annual cycle representative of many migratory animal species, illustrated through the American Redstart (Setophaga ruticilla). The redstart breeds in the northern part of eastern North America and western Canada between May and July, and overwinters in Central America and northern South America from September to March. Key food resources and habitats are small insects in open mature woodland habitats. Spring and fall migrations can require up to two months of travel with frequent stopover. Critically, the science of migratory connectivity has a focus not only on the distinct stages of an annual migratory cycle, but also the "seasonal effects" which carry over from one stage to the next. For American Redstarts, key insights are summarized in the figure below (based on research in Norris et al. 2006).

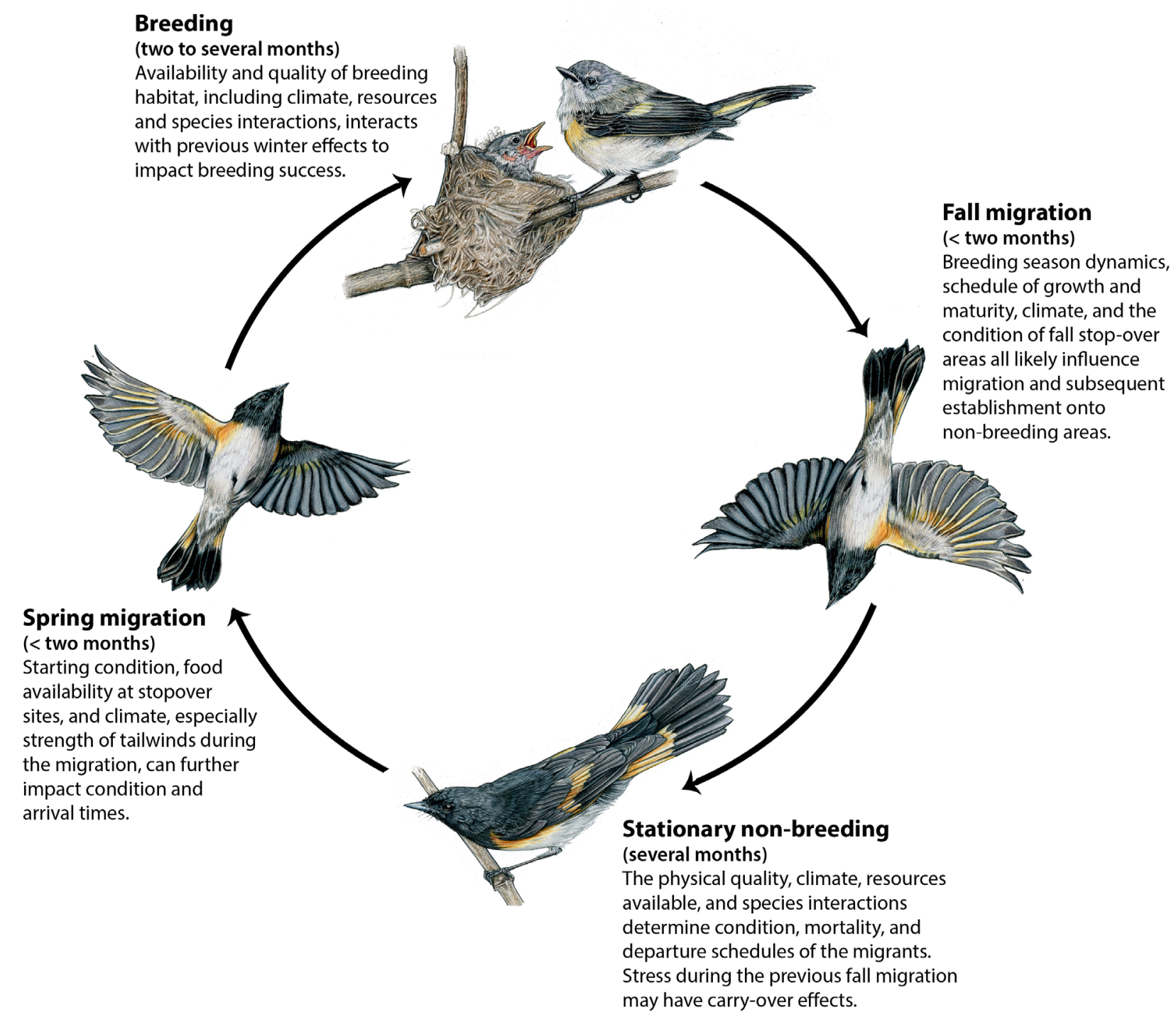


The need for information on migratory connectivity has led to innovative approaches for tracking animal movements in recent years, including the use of citizen science observations, satellite GPS transmitters, miniaturized archival geolocators, and isotopic investigations of animal origins (e.g., Hobson et al. 2014, Fraser et al. 2016, Fudickar and Ketterson 2018) (Supporting Information, Table S1). Deploying these technologies is needed to inform modeling approaches, including stage-to-stage transitions and migratory flow networks (Taylor et al. 2016), with the goal of understanding migratory connectivity and stressors across the annual cycle (Hostetler et al. 2015, Taylor et al. 2016). Insights from these analyses can help establish protected areas, advance targeted restoration, regulate human activity, and advance public awareness of sensitive places and critical times. For example, beginning in 2014, an innovative program spearheaded by The Nature Conservancy used knowledge of the geography of shorebird migration collected by citizen scientists to advance just-in-time conservation (Robbins 2014, Reynolds et al. 2017). They paid California farmers to leave specific rice fields flooded for relatively short intervals, providing stopovers for migratory birds threatened by severe drought during their southern migration.

The pathway forward for migratory species conservation rests on integrating advances in the science of migratory connectivity into more effective conservation strategies that address threats throughout the annual migratory cycle. From the perspective of conservation planning, it is critical to know where interventions are likely to be most cost effective. Spatially explicit data on population sensitivity needs to be overlaid with spatially explicit data on costs of conserving particular habitats. Scaling up from studies of individual species, migration studies can also highlight systemic threats to biodiversity and build the case for action on larger-scale issues, as discussed after the monarch case is introduced below.

\section{Monarch Butterfly Migration: Threats and Strategies for Protection}

The promises and limitations of migratory species science and conservation can be highlighted through the case of monarch butterfly (Danaus plexippus) migration in eastern North America. Monarchs span three countries and travel several thousand kilometers throughout their annual cycle (Figure 3). During the spring and summer, monarchs fly north over multiple breeding generations across the U.S. and southern Canada, laying eggs on milkweed host plants as their larval food. Butterflies that emerge in late summer migrate south to overwintering sites in high altitude fir forests in the neovolcanic mountains of central Mexico.

Since the discovery of the monarchs' overwintering grounds in Mexico in 1975, conservation concerns have been raised, especially because of the narrow geographic location and specific habitat requirements of the overwintering sites (Brower et al. 2012, Vidal et al. 2014, Agrawal 2017). In 1983, the IUCN designated the monarch migration as a threatened phenomenon, noting that although monarchs are widespread globally and not likely to go extinct as a species, the North American migration was at risk, mainly owing to threats from logging at the overwintering sites (Brower et al. 2002). Despite further efforts to protect the monarchs' winter forests, which include designation of the Monarch Butterfly Biosphere Reserve as a UNESCO World Heritage Site (2008), estimates of overwintering monarchs have declined dramatically since the late 1990s, with the lowest numbers recorded in 2012-2015 (Figure 4). This trend required two decades of monitoring to resolve, owing to historically strong population fluctuations both within and between years (Brower et al. 2012). 
Figure 3. Annual migratory cycle and key risks identified to date for North American monarch butterflies.

1. Monarchs overwinter from November to March in high elevation fir forests in Central Mexico (red circle) that have been protected by Mexico since the mid-1980s, and became UNESCO World Heritage Sites in 2008. Logging operations, including small scale subsistence logging and larger harvesting, continue to degrade the sites, although careful monitoring of forests, stronger protections from federal police and reforestation efforts have increased in recent years.

2. The spring migration and recolonization starts in mid to late March each year and spans 2-3 generations as monarchs move northward. Only recently has the US Fish and Wildlife Service encouraged habitat restoration and protection in the south-central US (including Texas) during the first spring generation.

3. Widespread discussion about the role of habitat quality and milkweed abundance in monarch summer breeding range, which spans across the central and eastern US and southern Canada, has prompted analysis of citizen science data, modeling efforts, and habitat restoration of milkweed plants in the Midwestern and Northeastern USA. US Fish and Wildlife Service and Forest Service are engaged in developing conservation plans, but these are not legally binding.

4. A role for the fall southern migration (dashed arrows), which extends from late August to early November, in the decline of monarchs has been hypothesized, but few data are available on habitat needs and migratory mortality, and no protections for migrating monarchs in the US or Canada are in place.

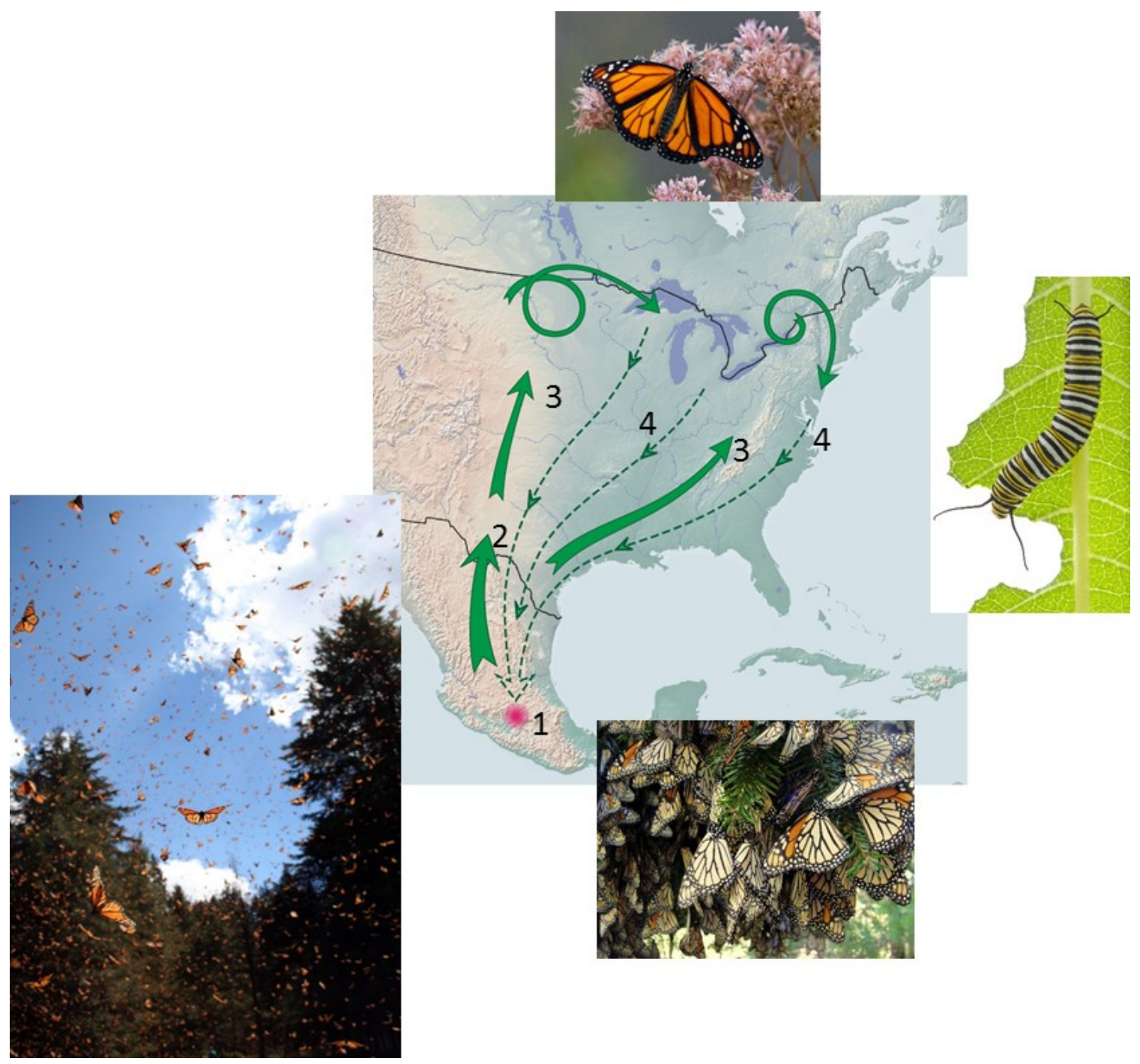


Since 2011, scientific focus on the causes of monarch declines shifted to milkweed host plant declines throughout the breeding range, in large part owing to widespread spraying of herbicides and the planting of herbicide tolerant crops in the U.S. (Flockhart et al. 2015, Inamine et al. 2016). This attention has motivated recent efforts to increase monarch breeding habitats by planting milkweed and nectar resources, especially in the central U.S. (Lewandowski and Oberhauser 2016). Other possible threats, including those during the monarchs' fall migration, remain relatively unexplored, and comprehensive analyses of existing data and integrative modeling approaches are needed to understand migratory connectivity and identify where in their annual cycle conservation efforts will have the greatest impact (Flockhart et al. 2015, Inamine et al. 2016, Oberhauser et al. 2017, Agrawal and Inamine 2018). In the absence of data, some current modeling efforts rely heavily on "expert opinion" to define key parameters such as migratory mortality (Flockhart et al. 2015, Oberhauser et al. 2017, Thogmartin et al. 2017a).

Data from multiple citizen science monitoring efforts at continent-wide scales could be used to document shifts in monarchs' migration patterns, and to resolve the absence of a strong signal of decline at some points in the monarchs' annual cycle. As a case in point, controversy was sparked in 2012 when an analysis of two citizen science fall migration census programs at northern stopover sites en route to Mexico revealed no evidence of decline (Davis 2012).

Subsequent analyses of butterfly count data on the summer breeding grounds also showed no consistent downward trend (Ries et al. 2015), and an assessment of connectivity between the successive stages did not point to milkweed limitation during the breeding season as a cause of declines in the wintering population (Inamine et al. 2016, Agrawal and Inamine 2018). Rising levels of monarch disease over the past two decades were recently reported from a North American monitoring program, and this has now been included in modelling population trends (Thogmartin et al. 2017b). Despite the assumption that restoring and protecting breeding habitat in the Midwestern U.S. is key to sustaining monarch reproduction, a long-term analysis of natal origins of overwintering monarchs showed that nearly two thirds of monarchs in central Mexico originate from other parts of North America (Flockhart et al. 2017), suggesting that reversing habitat loss in the Midwest will not protect the majority of the migratory population. Future modeling efforts, novel approaches to historical data, and assessment of monarch mortality during migration are especially needed to resolve the apparently contradictory trends in monarch abundance data (e.g., Flockhart et al. 2017, Oberhauser et al. 2017), and to better integrate the roles of lesser-appreciated threats to monarchs (e.g., droughts, snowstorms, roadside mortality, insecticides, and disease).

The record low monarch numbers observed at overwintering sites between 2012-2015 engendered an immediate response from the public and generated high-level attention from North American leaders on a level that has never been seen for other declining insects (Diffendorfer et al. 2014). Leaders of Mexico, US and Canada created domestic task forces to address the problem. Current recovery efforts span federal and state government agencies and include action plans by NGOs, schools, and individuals. In the U.S., a petition to list monarchs as threatened under the Endangered Species Act in August 2014 has further thrust monarchs into view as a species in need of immediate action. The U.S. Fish and Wildlife Service is currently conducting analyses of population trends and migratory connectivity, and the agency is required by law to reach a decision about federal protection by June 2019.

The monarch enjoys iconic status premised on decades of scientific study, educational programming, and popular engagement (Gustafsson et al. 2015). Yet the future of their migratory cycle remains in doubt, even though the species itself is unlikely to go extinct. Growth in global 
Figure 4. The population decline of monarch butterflies as measured by hectares of forest occupied in the highlands of Central Mexico during overwintering (data courtesy of WWF Mexico). This pattern of decline has not been strongly observed at other stages in the annual migratory cycle, such counts of summer adults in the breeding range or fall migration counts at northern stopover sites.

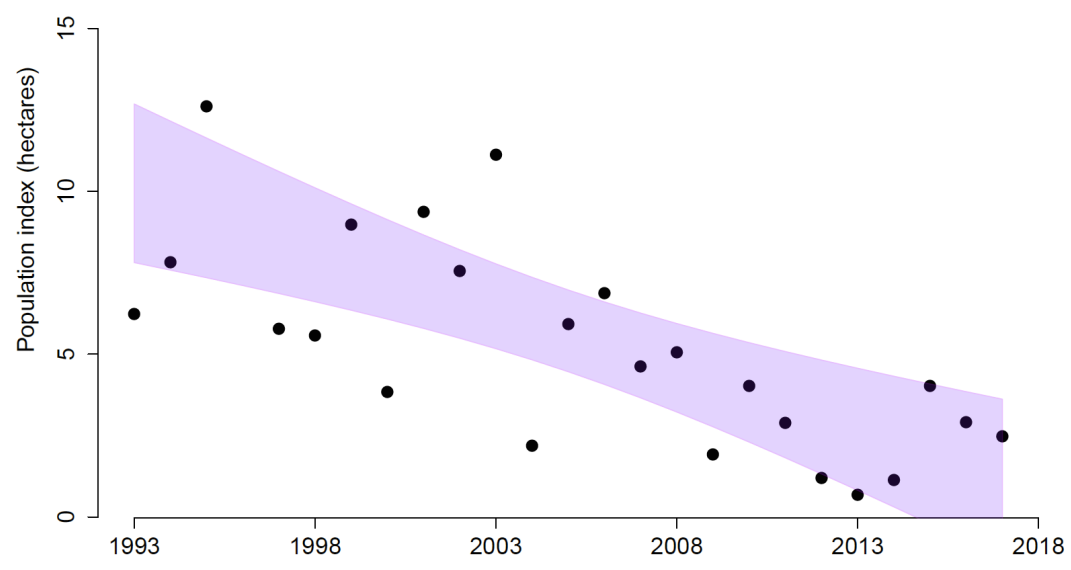


demand for agricultural products, intensification of corn and soybean production and pest control, and land use change linked to urbanization and infrastructure reflect economic growth and expanded demands on ecosystem processes. Thus, despite the monarch's status in our collective consciousness and the 1996 chartering of the Trilateral Committee for Wildlife and Ecosystem Conservation and Management between Canada-US-Mexico, declines have continued. The monarch case suggests that sustained scientific engagement and the mobilization of conservation responses ranging from raising the awareness of generations of schoolchildren, organization of vast citizen science networks, and public statements of cooperation among the political leaders of North America is not enough to address the population decline. Below, we outline several approaches at the science-policy interface that could show promise for conserving the migrations of monarchs and diverse other species.

\section{Moving forward with integrating science into policies}

The case of the monarch butterfly highlights multiple challenges that migratory species face. Even when seasonal movements are well-known, movement across national borders, and a multitude of threats, introduce a need for cross-jurisdictional cooperation. Differences between countries in conservation goals, laws and governance capacity pose particular challenges to cross-boundary conservation. Easing the diverse stresses in multiple locations and stages of the migration will be critical for monarch conservation, and could benefit a large number of other species including insect pollinators, wildflowers and birds. In what follows, we explore examples of international conservation initiatives and the implications and limitations of migratory science for enhancing their effectiveness (see Supplemental Information, Table S2). These ongoing efforts address (i) direct threats during species' annual cycles, (ii) systemic threats to regional or global ecosystems, and (iii) pervasive political and economic drivers underlying biodiversity declines.

\section{International Policies Targeting Species-level Conservation}

The emerging science of migratory connectivity, particularly understanding detailed migratory pathways and demographic perturbations, can improve the effectiveness of international efforts to prevent direct threats at the species level, including overharvesting and habitat loss. Treaties aimed primarily at restricting harvesting, including international trade, are among the earliest and most common international conservation efforts. Examples of treaties aimed directly at lowering the harvest of wildlife include the Northern Fur Seals Agreement (fur seals), the Migratory Bird Treaty of 1916 (migratory birds) and the International Whaling Convention (whales) (see Table S2). These treaties have been fairly effective in reducing the mortality of species that cross international borders.

The global Convention on International Trade of Endangered Species (CITES, 1987) does not prohibit the harvesting of species directly, but instead restricts the international trade in threatened or endangered species or their parts. A benefit of CITES is that countries that sign the treaty pledge to pass domestic legislation and train enforcement officers, and violating countries may be subject to sanctions (Vasquez 2003). A recent case involving Saiga antelope (a highly mobile nomadic species) exemplifies how CITES pressured China and other countries trading in 
Saiga horns towards enforcement against poaching (Von Meibom et al. 2010). Saiga also benefit from a cross-convention collaboration between CITES and the Convention on Migratory Species (see below). Additional high profile examples of protection under CITES include efforts to conserve elephants, birds in the pet trade, and sea turtles.

If the major driver of migratory species decline is over-harvesting, a policy response that restricts or prevents harvesting at vulnerable times or locations is relatively simple and can be straightforward to enforce, depending on the motivation for harvesting. For some species, recovery can be significant (Table S2). For many other species such as the monarch butterfly discussed above, habitat loss, appears to be a major cause of declines. In these cases, other initiatives have aimed at protecting habitats of high conservation value. For example, the Convention on Wetlands of International Importance Especially as Waterfowl Habitat (Ramsar Convention) is designed to provide international support for protecting wetlands that support significant populations of migratory waterfowl. Parties designate wetlands for inclusion on an internationally recognized list that makes them eligible for financial and other support. Currently, the Ramsar Convention covers 2,288 wetland sites (totaling nearly 221 million hectares) in 169 countries. The Convention both explicitly and implicitly considers migration in its activities. The same basic approach, without a specific focus on migration, leads to the listing and protection of some high value natural sites under the UNESCO Convention Concerning the Protection of the World Cultural and Natural Heritage (the "World Heritage Convention"). Indeed, as noted above, the monarch butterfly's wintering grounds were listed on the World Natural Heritage List, but this added protection did not stem the decline, in part due to threats outside the protected area, illegal logging that continued within the protected area, and other potential stressors such as climate change, pesticides and disease.

Arguably the most comprehensive framework for addressing migration, including both overharvesting and habitat loss, is the Convention on Migratory Species (CMS, Table 2). The CMS provides a framework for developing treaties and other initiatives tailored to specific species or groups of species, and could eventually promote the conservation of a wide range of migratory species across diverse taxonomic group and habitats used. It currently consists of seven binding agreements and 19 memoranda of understanding. Countries that join one of the agreements (and contain part of the range of endangered migratory species) are expected to prohibit the taking of that species, conserve and restore its habitat, and reduce other threats facing the species' existence. Non-migratory species that have transboundary distributions can also be protected under the CMS. Thus, the CMS focuses the attention of the conservation community on species that require international agreements for their protection, and assigns responsibility for conservation to specific countries (Hensz and Soberón 2018).

The impact of the CMS is currently constrained by a lack of resources for enforcement, and because participation by key countries such as the United States remains limited (Marra et al. 2011). Another major shortcoming of the CMS is the limited number of species for which agreements have been negotiated; only a small number of species are covered, and sometimes only for part of their range. Nonetheless, CMS is gaining greater acceptance and provides a framework to fill crucial conservation gaps, but this depends on enhanced scientific understanding of migration and engagement of relevant countries. Beyond strengthening the CMS, the Ramsar Convention (noted earlier) could be used as a model through which science can inform conservationists about protecting critical migratory hot spots for species other than waterfowl. 
Recruiting more Western Hemisphere nations to join existing conventions remains a high priority, but it is also only a first step. Care should be taken to not let international agreements legitimate what could be seen as superficial conservation strategies. Domestic legislation that binds nations to action consistent with the treaties is typically lacking under these global agreements (except CITES discussed above), and enforcement is highly uneven, producing significant failures of implementation. For example, the existing Trilateral Committee engaged in monarch conservation has yet to influence major policy decisions and legal enforcement across Canada, USA, and Mexico. Conservation commitments could be targeted at a broad array of sectors, including regulation and investment applied to transportation, public lands management, and agriculture.

Within countries or political unions, major legislation has had some success, but for migratory species, success is constrained by geopolitical boundaries. For example, the Endangered Species Act (ESA) of 1973 protects threatened and endangered species in the USA without limitation to specific causes of species decline or methods of protection. Successful protections have improved populations of several migratory species, including the bald eagle, impacted by DDT, as well as the more recent increase in the Kirtland's warbler population. Lack of funding and the resulting listing backlog at the U.S. Fish and Wildlife Service, combined with the limited regulatory reach outside the USA, reduce the ESA's effectiveness, especially for migratory species. Current efforts to diminish legislated protections for species under the ESA is particularly worrying, as this development highlights the weak political consensus for combatting extinction. The European Union Birds Directive (EUBD), a legal act of the EU, similarly compels member nations to achieve broad scale conservation goals. A recent study addressed bird population trends of species protected by the EUBD versus unprotected birds, including migratory species (Sanderson et al. 2016). Although protected species showed more positive population trends than unprotected species, this difference was absent for long-distance migrants. The models evaluated by Sanderson et al. (2016) suggested that protections resulting from the EUBD produced some protection in the face of climate change, but it remains unclear as to why migratory species were consistently less positively impacted by the regulation.

\section{Regional-scale Policy Responses to Systemic Stresses}

As a complement to species-specific and place-based conservation efforts, interventions focused around broader-scale threats to biodiversity, including species invasions and habitat loss, are critical to reducing stresses on migratory species. Such threats can be especially harmful for migratory animals that encounter a wide variety of environments and potential stressors throughout their annual cycle (Opdam and Wascher 2004). The primary response to land conversion is either to zone off some areas from conversion or to mitigate the impacts of intensified use. However, this patchwork approach to habitat conservation efforts is particularly ineffective at countering the threat of widespread land conversion, and less than $7 \%$ of terrestrial land is set aside for protection at a global scale. Many non-treaty initiatives have tried to address the patchwork problem by expanding the geographic scope of conservation efforts. For example, the Yellowstone-to-Yukon Conservation Initiative represents an ambitious and innovative approach to trans-boundary science, environmental management, and policy (Graumlich and Francis 2010). Globally, the Achi targets (https://www.cbd.int/sp/targets/) under the Convention on Biological Diversity aim to increase conservation areas to $17 \%$ of land and $10 \%$ of oceans by 
2020. More ambitious still is the Half Earth goal championed by E.O. Wilson, which calls for the protection of half of the earth to maintain most of the life forms. Migratory connectivity science, in addition to other approaches (e.g., Redding et al. 2015), could be useful to prioritize the highest value regions and to support the creation of conservation corridors linking larger scale efforts. Beyond regulating land use and land cover change in conservation corridors and pursuing habitat restoration, it is possible to imagine targeted efforts in these zones focused around reductions in pesticide use, control of invasive species, and reductions in mortality linked to infrastructure such as roads and building strikes.

In some locations, habitat restoration and improved management can create and protect crucial resources. As one example, the restoration of prairie potholes and other wetland habitats in the U.S. and Canada offers critical stopover habitat for migratory birds, in addition to conserving biodiversity more generally (Naugle et al. 2001). For monarch butterflies, it has been suggested that nectar resources from flowers may be critically limiting during migration (Inamine et al. 2016), and efforts to promote nectar availability are underway within the migratory flyway. Where changes in land management will disrupt livelihoods and make marginalized people and cultures less secure, prior informed consent and compensation are needed to advance fair conservation arrangements (Kiss 2004).

Bans placed on pesticides such as dichlorodiphenyltrichloroethane (DDT) have been implicated in the recovery of some migratory species (Cade et al. 1988), but differences in pesticide regulation across nations continues to be an issue (Mora 1997). The current rise in knowledge about neonicotinoid insecticides on biodiversity (van der Sluijs et al. 2015, Mitchell et al. 2017) reminds of the importance of continual risk assessments of emerging threats. The emerging science has contributed to the abandonment of several neonicotinoids by countries in Europe and parts of Canada, but not in the United States and Mexico. The US Environmental Protection Agency is currently reviewing evidence of neonicotinoid effects, where tradeoffs between food prices, human health, R\&D in the pesticide industry, and the conservation of biodiversity will be considered.

The widespread threats of invasive species (Molnar et al. 2008, Vilà et al. 2011) and climate change (Frost et al. 2016, Sanderson et al. 2016) have been widely recognized for both terrestrial and marine species, but international agreements and national legislation have lagged behind this knowledge. At present, most conservation policies do not mitigate the effects of invasive species and climate change on migratory species, and we believe this to be both a problem and an opportunity. Because interventions targeting such threats can resonate with a wide variety of interest groups (e.g., across taxa, environmental media, and welfare of humans and non-humans) across numerous jurisdictions, organizing them into effective advocacy coalitions is difficult, but with increases in migratory science demonstrating migratory connectivity, the emergence of more robust advocacy coalitions (Sabatier 1988) may be possible. Migratory species conservation is important in and of itself, but advocates for migratory species need to build diverse partnerships to construct and maintain popular and policy salience.

\section{Addressing Global-scale Socioeconomic Drivers of Species Declines}

Despite the iconic status of many migratory species, lack of political will in the face of significant economic and political forces limit effective responses to population declines. This suggests that protecting the world's migratory species also requires a renewed conversation 
about conservation and the limits of science and policy as currently structured and practiced. Despite promising breakthroughs in conservation science, including in migratory connectivity research, large-scale drivers, such as material consumption and human appropriation of net primary productivity (Krausmann et al. 2013), are swamping our capacity to respond. At this macro-scale, economic policy and practice must better incorporate the inevitable limits to sustainability of our ecological systems.

The implications of the human population and explosive growth in resource consumption for ecology and conservation indicate that novel modes of social regulation of economic activity are crucially needed. Within the fields of environmental social science and humanities, there have been long-standing debates on the potential for transitions to sustainability, and the interplay between technology, politics, and environmental change (Box 1). The complex and indirect nature of connections between material problems of ecology and social responses have been amply discussed yet are difficult to address (Blühdorn 2007). When examined empirically and critically, contemporary conservation policy is essentially not capable of producing major conservation outcomes (i.e., stemming population and extinction of large numbers of species). In this sense, the function of much contemporary conservation policy is to legitimate "business as usual" rather than arrest or reverse degradation. In the language of environmental politics, these policies are "post-ecological” (Blühdorn 2013). It is essential that conservation scientists recognize this perverse dynamic and do not allow their work to legitimize policies and social arrangements that further advance unsustainability.

Globalization of commerce and finance are presenting new opportunities for negotiating conservation impacts in the context of trade agreements. The US-Peru Free Trade Agreement, for example, has a detailed section requiring enhanced forest conservation efforts in Peru. Most international project financing to developing countries now include environmental standards, including some aimed at nature conservation. Leading NGOs are working with multinational companies to introduce rigor and accountability into voluntary standards for sustainable commodity systems and value chains (e.g., palm oil, cocoa) (Carlson et al. 2018). Development banks also have power to impact conservation when they are committed to environmentally responsible guidelines (as recently advanced in the CMS). More generally, concerns about environmental conservation have begun to creep into conversations about economic competitiveness and economic growth. Without engaging dynamics at these higher levels of problem definition and social organization, saving the Earth's great migrations, together with other efforts aimed at biodiversity conservation generally, will likely fail. Nation states are essential elements of international conservation strategy, but we must also engage economic actors and organizations of civil society operating at larger scales.

Finally, we question the typical invocation of 'policy' as a sufficient complement to 'science' in guiding conservation efforts. Some analyses suggest limits to the dominant model in which science informs, motivates, and legitimizes policy, and where policy then attempts to control social processes and alter resource flows in a manner that protects ecosystems. A more probing analysis and reconstruction of science-policy-practice interfaces is needed (Weichselgartner and Kasperson 2010, Gustafsson et al. 2017). New relationships between science, citizens and policy processes could produce novel approaches to advance conservation. While migratory species conservation is a daunting challenge because of the social and geopolitical boundaries that these species cross, the phenomenon of migration and the way it connects humanity across boundaries may provide a catalyst for deeper conversations about sustainability. 
Part of the societal response to declining biodiversity must reflect changes in human relationships to nature. This can be aided by further investments in citizen science programs that combine data collection and public education, ecological literacy, and advances in transdisciplinary research. The iconic status of some migratory species, like the monarch butterfly, and their capacity to highlight interdependence among people and places are potent resources for initiating and sustaining dialogue about the value of conserving nature in a time of rapid and uneven economic growth. While migratory animals pose particular conservation challenges, they are often widely recognized and cherished, creating opportunities to place conservation on the policy agenda and to advance public education.

\section{References}

Agrawal, A. A. 2017. Monarchs and milkweed: A migrating butterfly, a poisonous plant, and their remarkable story of coevolution. Princeton University Press, Princeton, NJ.

Agrawal, A. A., and H. Inamine. 2018. Mechanisms behind the monarch's decline. Science 360:1294-1296.

Asafu-Adjaye, J., L. Blomquist, S. Brand, B. Brook, R. Defries, E. Ellis, C. Foreman, D. Keith, M. Lewis, and M. Lynas. 2015. An ecomodernist manifesto. https://static1.squarespace.com/static/5515d9f9e4b04d5c3198b7bb/t/552d37bbe4b07a7dd69fcdbb/1429026747046/An+Ecomodernist+Manifesto.pdf.

Bauer, S., and B. J. Hoye. 2014. Migratory animals couple biodiversity and ecosystem functioning worldwide. Science 344:1242552.

Blühdorn, I. 2007. Sustaining the unsustainable: Symbolic politics and the politics of simulation. Environmental politics 16:251-275.

Blühdorn, I. 2013. The governance of unsustainability: ecology and democracy after the post-democratic turn. Environmental Politics 22:16-36.

Bogdanova, M. I., F. Daunt, M. Newell, R. A. Phillips, M. P. Harris, and S. Wanless. 2011. Seasonal interactions in the black-legged kittiwake, Rissa tridactyla: links between breeding performance and winter distribution. Proceedings of the Royal Society of London B: Biological Sciences:rspb20102601.

Bowlin, M. S., I.-A. Bisson, J. Shamoun-Baranes, J. D. Reichard, N. Sapir, P. P. Marra, T. H. Kunz, D. S. Wilcove, A. Hedenström, and C. G. Guglielmo. 2010. Grand challenges in migration biology. Integrative and comparative biology 50:261-279.

Brower, L. P., G. Castilleja, A. Peralta, J. Lopez-Garcia, L. Bojorquez-Tapia, S. Diaz, D. Melgarejo, and M. Missrie. 2002. Quantitative changes in forest quality in a principal overwintering area of the monarch butterfly in Mexico, 1971-1999. Conservation Biology 16:346-359.

Brower, L. P., O. R. Taylor, E. H. Williams, D. A. Slayback, R. R. Zubieta, and M. I. Ramirez. 2012. Decline of monarch butterflies overwintering in Mexico: is the migratory phenomenon at risk? Insect Conservation and Diversity 5:95-100.

Cade, T. J., J. H. Enderson, C. Thelander, and C. White. 1988. Peregrine falcon populations. Their management and recovery. The Peregrine Fund, Boise, ID.

Carlson, K. M., R. Heilmayr, H. K. Gibbs, P. Noojipady, D. N. Burns, D. C. Morton, N. F. Walker, G. D. Paoli, and C. Kremen. 2018. Effect of oil palm sustainability certification on deforestation and fire in Indonesia. Proceedings of the National Academy of Sciences 115:121-126.

Chertow, M. R. 2000. The IPAT equation and its variants. Journal of Industrial Ecology 4:13-29.

Davis, A. K. 2012. Are migratory monarchs really declining in eastern North America? Examining evidence from two fall census programs. Insect Conservation and Diversity 5:101-105.

Diffendorfer, J. E., J. B. Loomis, L. Ries, K. Oberhauser, L. Lopez-Hoffman, D. Semmens, B. Semmens, B. Butterfield, K. Bagstad, and J. Goldstein. 2014. National valuation of monarch butterflies indicates an untapped potential for incentive-based conservation. Conservation Letters 7:253-262.

Fiedler, W. 2003. Recent changes in migratory behaviour of birds: a compilation of field observations and ringing data. Pages 21-38 in P. Berthold, E. Gwinner, and E. Sonnenschein, editors. Avian migration. Springer, Berlin.

Flockhart, D., L. P. Brower, M. I. Ramirez, K. A. Hobson, L. I. Wassenaar, S. Altizer, and D. R. Norris. 2017. Regional climate on the breeding grounds predicts variation in the natal origin of monarch butterflies overwintering in Mexico over 38 years. Global Change Biology.

Flockhart, D. T. T., J. B. Pichancourt, D. Ryan Norris, and T. G. Martin. 2015. Unraveling the annual cycle in a migratory animal: Breeding-season habitat loss drives population declines of monarch butterflies. Journal of Animal Ecology 84:155-165.

Fraser, K., A. Shave, A. Savage, A. Ritchie, K. Bell, J. Siegrist, J. Ray, K. Applegate, and M. Pearman. 2016. Determining fine-scale migratory connectivity and habitat selection for a migratory songbird by using new GPS technology. Journal of Avian Biology.

Frost, M., G. Bayliss-Brown, P. Buckley, M. Cox, S. R. Dye, W. G. Sanderson, B. Stoker, and N. Withers Harvey. 2016. A review of climate change and the implementation of marine biodiversity legislation in the United Kingdom. Aquatic Conservation: Marine and Freshwater Ecosystems 26:576-595.

Fudickar, A. M., and E. D. Ketterson. 2018. Genomes to space stations: the need for the integrative study of migration for avian conservation. Biology letters 14:20170741.

Graumlich, L., and W. L. Francis. 2010. Moving toward climate change adaptation: The promise of the Yellowstone to Yukon conservation initiative for addressing the region's vulnerability to climate disruption. Yellowstone to Yukon Conservation Initiative, Canmore, Alberta, Canada.

Gustafsson, K. M., A. A. Agrawal, B. V. Lewenstein, and S. A. Wolf. 2015. The monarch butterfly through time and space: the social construction of an icon. BioScience:biv045.

Gustafsson, K. M., S. A. Wolf, and A. A. Agrawal. 2017. Science-Policy-Practice Interfaces: Emergent knowledge and monarch butterfly conservation. Environmental Policy and Governance.

Harris, G., S. Thirgood, J. G. C. Hopcraft, J. P. Cromsigt, and J. Berger. 2009. Global decline in aggregated migrations of large terrestrial mammals. Endangered Species Research 7:55-76

Hensz, C. M., and J. Soberón. 2018. Participation in the convention on migratory species: A biogeographic assessment. Ambio:1-8.

Hobson, K. A., S. L. Van Wilgenburg, J. Faaborg, J. D. Toms, C. Rengifo, A. L. Sosa, Y. Aubry, and R. Brito Aguilar. 2014. Connecting breeding and wintering grounds of Neotropical migrant songbirds using stable hydrogen isotopes: a call for an isotopic atlas of migratory connectivity. Journal of Field Ornithology 85:237-257.

Hostetler, J. A., T. S. Sillett, and P. P. Marra. 2015. Full-annual-cycle population models for migratory birds. The Auk 132:433-449.

Hurlbert, A. H., and Z. Liang. 2012. Spatiotemporal variation in avian migration phenology: citizen science reveals effects of climate change. Plos One 7:e31662.

Inamine, H., S. P. Ellner, J. P. Springer, and A. A. Agrawal. 2016. Linking the continental migratory cycle of the monarch butterfly to understand its population decline. Oikos 125:1081-1091.

Kiss, A. 2004. Is community-based ecotourism a good use of biodiversity conservation funds? Trends in Ecology \& Evolution 19:232-237.

Krausmann, F., K.-H. Erb, S. Gingrich, H. Haberl, A. Bondeau, V. Gaube, C. Lauk, C. Plutzar, and T. D. Searchinger. 2013. Global human appropriation of net primary production doubled in the 20th century. Proceedings of the National Academy of Sciences 110:10324-10329. 
Leadley, P., V. Proença, J. Fernández-Manjarrés, H. M. Pereira, R. Alkemade, R. Biggs, E. Bruley, W. Cheung, D. Cooper, and J. Figueiredo. 2014. Interacting regional-scale regime shifts for biodiversity and ecosystem services. BioScience:biu093.

Lewandowski, E. J., and K. S. Oberhauser. 2016. Contributions of citizen scientists and habitat volunteers to Monarch Butterfly conservation. Human Dimensions of Wildlife:1-16.

Marra, P. P., E. B. Cohen, S. R. Loss, J. E. Rutter, and C. M. Tonra. 2015. A call for full annual cycle research in animal ecology. Biology Letters 11:20150552.

Marra, P. P., D. Hunter, and A. M. Perrault. 2011. Migratory connectivity and the conservation of migratory animals. Environmental Law 41:317.

Martin, T. G., I. Chadès, P. Arcese, P. P. Marra, H. P. Possingham, and D. R. Norris. 2007. Optimal conservation of migratory species. PLoS One 2:e751.

Meixler, M. S., M. B. Bain, and M. T. Walter. 2009. Predicting barrier passage and habitat suitability for migratory fish species. Ecological Modelling 220:2782-2791.

Mitchell, E., B. Mulhauser, M. Mulot, A. Mutabazi, G. Glauser, and A. Aebi. 2017. A worldwide survey of neonicotinoids in honey. Science 358:109-111.

Molnar, J. L., R. L. Gamboa, C. Revenga, and M. D. Spalding. 2008. Assessing the global threat of invasive species to marine biodiversity. Frontiers in Ecology and the Environment 6:485-492.

Mora, M. A. 1997. Transboundary pollution: persistent organochlorine pesticides in migrant birds of the southwestern United States and Mexico. Environmental Toxicology and Chemistry 16:3-11.

Musiega, D. E., K. Sanga-Ngoie, and K. Fukuyama. 2006. A framework for predicting and visualizing the East African wildebeest migration-route patterns in variable climatic conditions using geographic information system and remote sensing. Ecological Research 21:530-543.

Naugle, D. E., R. R. Johnson, M. E. Estey, and K. F. Higgins. 2001. A landscape approach to conserving wetland bird habitat in the prairie pothole region of eastern South Dakota. Wetlands 21:1-17.

Norris, D. R., P. P. Marra, G. J. Bowen, L. M. Ratcliffe, J. A. Royle, and T. K. Kyser. 2006. Migratory connectivity of a widely distributed songbird, the American Redstart (Setophaga ruticilla). Ornithological Monographs 2006:14-28.

Norris, D. R., P. P. Marra, T. K. Kyser, T. W. Sherry, and L. M. Ratcliffe. 2004. Tropical winter habitat limits reproductive success on the temperate breeding grounds in a migratory bird. Proceedings of the Royal Society of London B: Biological Sciences 271:59-64.

Oberhauser, K., R. Wiederholt, J. E. Diffendorfer, D. Semmens, L. Ries, W. E. Thogmartin, L. Lopez-Haffman, and B. Semmens. 2017. A trans-national monarch butterfly population model and implications for regional conservation priorities. Ecological Entomology 42:51-60.

Opdam, P., and D. Wascher. 2004. Climate change meets habitat fragmentation: linking landscape and biogeographical scale levels in research and conservation. Biological conservation 117:285-297.

Pulido, F., and P. Berthold. 2010. Current selection for lower migratory activity will drive the evolution of residency in a migratory bird population. Proceedings of the National Academy of Sciences:200910361.

Redding, D. W., A. O. Mooers, Ç. H. Şekercioğlu, and B. Collen. 2015. Global evolutionary isolation measures can capture key local conservation species in Nearctic and Neotropical bird communities. Phil. Trans. R. Soc. B 370:20140013.

Reynolds, M. D., B. L. Sullivan, E. Hallstein, S. Matsumoto, S. Kelling, M. Merrifield, D. Fink, A. Johnston, W. M. Hochachka, and N. E. Bruns. 2017. Dynamic conservation for migratory species. Science Advances 3:e1700707.

Ries, L., D. J. Taron, and E. Rendón-Salinas. 2015. The disconnect between summer and winter monarch trends for the eastern migratory population: possible links to differing drivers. Annals of the Entomological Society of America 108:691-699.

Robbins, J. 2014. Paying farmers to welcome birds. New York Times (April 15, D1), New York.

Runge, C. A., T. G. Martin, H. P. Possingham, S. G. Willis, and R. A. Fuller. 2014. Conserving mobile species. Frontiers in Ecology and the Environment 12:395-402.

Sabatier, P. A. 1988. An advocacy coalition framework of policy change and the role of policy-oriented learning therein. Policy sciences 21:129-168.

Sanderson, F. J., R. G. Pople, C. Ieronymidou, I. J. Burfield, R. D. Gregory, S. G. Willis, C. Howard, P. A. Stephens, A. E. Beresford, and P. F. Donald. 2016. Assessing the performance of EU nature legislation in protecting target bird species in an era of climate change. Conservation Letters 9:172-180.

Satterfield, D. A., P. P. Marra, T. S. Sillett, and S. Altizer. 2018. Responses of migratory species and their pathogens to supplemental feeding. Phil. Trans. R. Soc. B 373:20170094.

Schnaiberg, A., D. N. Pellow, and A. Weinberg. 2002. The treadmill of production and the environmental state. Pages 15-32 in A. P. Mol and F. H. Buttel, editors. The environmental state under pressure. Emerald Group Publishing Limited.

Taylor, C. M., A. J. Laughlin, and R. J. Hall. 2016. The response of migratory populations to phenological change: a migratory flow network modelling approach. Journal of Animal Ecology 85:648-659.

Thogmartin, W. E., L. López-Hoffman, J. Rohweder, J. Diffendorfer, R. Drum, D. Semmens, S. Black, I. Caldwell, D. Cotter, and P. Drobney. 2017a. Restoring monarch butterfly habitat in the Midwestern US:'all hands on deck'. Environmental Research Letters 12:074005.

Thogmartin, W. E., R. Wiederholt, K. Oberhauser, R. G. Drum, J. E. Diffendorfer, S. Altizer, O. R. Taylor, J. Pleasants, D. Semmens, and B. Semmens. 2017b. Monarch butterfly population decline in North America: identifying the threatening processes. Open Science 4:170760.

van der Sluijs, J. P., V. Amaral-Rogers, L. Belzunces, M. B. van Lexmond, J.-M. Bonmatin, M. Chagnon, C. Downs, L. Furlan, D. Gibbons, C. Giorio, V. Girolami, D. Goulson, D. P. Kreutzweiser, C. Krupke, M. Liess, E. Long, M. McField, P. Mineau, E. A. D. Mitchell, C. A. Morrissey, D. A. Noome, L. Pisa, J. Settele, N. Simon-Delso, J. D. Stark, A. Tapparo, H. V. Dyck, J. v. Praagh, P. R. Whitehorn, and M. Wiemers. 2015. Conclusions of the Worldwide Integrated Assessment on the risks of neonicotinoids and fipronil to biodiversity and ecosystem functioning. Environ Sci Pollut Res 22:148-154.

Vasquez, J. C. 2003. Compliance and enforcement mechanisms of CITES. Pages 85-91 in S. Oldfield, editor. The Trade in Wildlife: Regulation for Conservation. Earthscan Publications Ltd, London.

Vidal, O., J. López--García, and E. Rendón-Salinas. 2014. Trends in deforestation and forest degradation after a decade of monitoring in the Monarch Butterfly Biosphere Reserve in Mexico. Conservation Biology 28:177-186.

Vilà, M., J. L. Espinar, M. Hejda, P. E. Hulme, V. Jarošík, J. L. Maron, J. Pergl, U. Schaffner, Y. Sun, and P. Pyšek. 2011. Ecological impacts of invasive alien plants: a meta-analysis of their effects on species, communities and ecosystems. Ecology letters 14:702-708.

Visser, M. E., A. C. Perdeck, J. H. van Balen, and C. Both. 2009. Climate change leads to decreasing bird migration distances. Global Change Biology 15:1859-1865.

Von Meibom, S., A. Vaisman, S. Neo Liang, J. Ng, and H. Xu. 2010. Saiga antelope trade: global trends with a focus on south-east Asia. TRAFFIC project report to the CITES Secretariat. TRAFFIC Europe (http://www.traffic.org/cites/).

Warrant, E., B. Frost, K. Green, H. Mouritsen, D. Dreyer, A. Adden, K. Brauburger, and S. Heinze. 2016. The Australian bogong moth Agrotis infusa: A longdistance nocturnal navigator. Frontiers in behavioral neuroscience $\mathbf{1 0}$.

Webster, M. S., P. P. Marra, S. M. Haig, S. Bensch, and R. T. Holmes. 2002. Links between worlds: unraveling migratory connectivity. Trends in Ecology \& Evolution 17:76-83

Weichselgartner, J., and R. Kasperson. 2010. Barriers in the science-policy-practice interface: Toward a knowledge-action-system in global environmental change research. Global Environmental Change 20:266-277.

Wilcove, D. S., and M. Wikelski. 2008. Going, going, gone: is animal migration disappearing. PLoS Biol 6:e188. 


\section{Box 1. A primer on the environmental sociology of sustainability issues}

Within the field of environmental sociology, debate about the interactions between society and environment has been framed as a contest between two contrasting models of human ecology. Both models address prospects for sustainability under capitalism:

- Ecological Modernization (EM) anticipates the progressive restructuring of society such that economic development is decoupled from ecological degradation. EM emphasizes that institutional changes can improve human wellbeing without degrading natural capital (Asafu-Adjaye et al. 2015). Technological innovation and changes in material consumption - as emphasized in Ehrlich and Holdren's famous IPAT formula - emerge from shifts in governance and culture, specifically new patterns of market competition and new understandings of humans' dependence on nature (Chertow 2000).

- Treadmill of Production emphasizes structural constraints to sustainability. Competition in markets drives successive rounds of capital investment at the level of firms and nation states, resulting in productivity gains, decreases in costs of finished goods, and expanded opportunities for material consumption by consumers. At the same time, the state fails to impose environmental controls on firms and sectors due to demands from workers and consumers to maintain purchasing power in the face of declining wages and bargaining power in a globalizing economy (Schnaiberg et al. 2002).

More recently, new theory has explicitly engaged with the symbolic dimensions of contemporary environmental politics (Blühdorn 2007) to emphasize the tension between acknowledgement of ecological crisis, on the one hand, and bedrock commitments to liberalism and capitalism, on the other. Faced with limited options, the resulting legitimacy crisis gives rise to gestures and performances of engagement with sustainability by states, markets, and individuals. In this formulation, conservation actions are gestures (including calls for a more authentic dialogue) that serve to legitimate precisely what it is they contest. In other words, applied ecology and conservation of individual species are understood as an essential resource for "sustaining the unsustainable" (Blühdorn 2007). For example, environmental policy and management concepts such as 'critical minimum habitat' derive from a scientific foundation that makes it possible to designate and protect habitat in some territory to avoid species extinctions. But even if we were to be persuaded that the habitat and population models (including stressors at all life stages across a migratory cycle) are robust, consideration of ongoing environmental change and issues such as migratory connectivity raise questions about the future of a given species, let alone the countless species at risk for which we do not mobilize a similar effort.

The implications of this analysis of environmental politics is that conservation science risks providing plausible deniability to elected officials, to corporations, and to consumer society. In this context, it is important that conservation science question its role in sustaining business as usual. Acknowledging that such issues are relevant to the discipline represents a first step. 


\section{Supporting Information, Table S1. Available technologies that enhance the ability of scientists to track migratory animals throughout their annual cycles.}

\begin{tabular}{|c|c|c|c|c|c|c|c|}
\hline Tracking Technique & Type of Animal & $\begin{array}{l}\text { Minimum } \\
\text { Body Size } \\
(\mathrm{g})\end{array}$ & Cost per Animal & Data Retrieval & Data Type & Data Accuracy & Life \\
\hline Individual Marking (bands, tags) & Any & None & Low: Close to $\$ 0$ & Recapture of animal & point location & Exact & years \\
\hline Passive Integrated Transponders (PIT tags) & $\begin{array}{l}\text { Amphibians, birds, } \\
\text { invertebrates, fish, } \\
\text { reptiles, mammals }\end{array}$ & 0.9 & Low: $\$ 2$ & $\begin{array}{l}\text { Recapture or when animal passes } \\
\text { antenna }\end{array}$ & point location & Exact & years \\
\hline Stable Isotopes (tissues) & Any & None & Low: $\$ 10$ & Tissue sample collection & latitudinal location & $600 \mathrm{~km}$ & $\mathrm{~N} / \mathrm{A}$ \\
\hline Molecular Markers (genetics) & Any & None & Low: $\$ 20$ & Tissue sample collection & $\begin{array}{l}\text { differentiated } \\
\text { populations }\end{array}$ & Broad & N/A \\
\hline MOTUS Network (nanotags) & $\begin{array}{l}\text { Large insects to } \\
\text { birds and bats }\end{array}$ & 10 & Medium: $\$ 75$ & $\begin{array}{l}\text { Receivers log signals from transmitters } \\
\text { when in range }\end{array}$ & point location & $15 \mathrm{~km}$ & $\begin{array}{l}\text { weeks to } \\
\text { months }\end{array}$ \\
\hline ICARUS network (International Space Station) & $\begin{array}{l}\text { Birds, mammals, } \\
\text { aquatic }\end{array}$ & 160 & Medium: $\$ 500-700$ & $\begin{array}{l}\text { Signals sent to handheld device or base } \\
\text { station }\end{array}$ & GPS & $5 \mathrm{~m}$ & $>1$ year \\
\hline Light-level Geolocation & Birds, fish & 8 & Medium: $\$ 200$ & Archival - requires recapture of animal & $\begin{array}{l}\text { light level to infer } \\
\text { latitude and longitude }\end{array}$ & $100-150 \mathrm{~km}$ & $>1$ year \\
\hline GPS Geolocation & Birds, mammals & 33.3 & Medium: > $\$ 390$ & Archival - requires recapture of animal & GPS locations & $10 \mathrm{~m}$ & months \\
\hline GSM Tags & $\begin{array}{l}\text { Birds, mammals, } \\
\text { aquatic }\end{array}$ & 566 & High: $\$ 2,500-4,000$ & $\begin{array}{l}\text { Uses the cellular network to receive and } \\
\text { transmit locations }\end{array}$ & GPS locations & $10 \mathrm{~m}$ & $\begin{array}{l}\text { months to }>1 \\
\text { year }\end{array}$ \\
\hline Acoustic Telemetry & Aquatic & 16.6 & High: $>\$ 3,000$ & $\begin{array}{l}\text { Receivers log signals from transmitters } \\
\text { when in range }\end{array}$ & point location & $<1$ to $>1,000 \mathrm{~m}$ & $\begin{array}{l}\text { days to }>1 \\
\text { year }\end{array}$ \\
\hline Radio (VHF) Telemetry & Birds, mammals & 6.6 & Medium: $\$ 100-200$ & $\begin{array}{l}\text { Antennas and receivers pick up unique } \\
\text { frequencies from a distance }\end{array}$ & point location & $10 \mathrm{~m}$ & $\begin{array}{l}\text { weeks to }>1 \\
\text { year }\end{array}$ \\
\hline Satellite Telemetry & $\begin{array}{l}\text { Birds, mammals, } \\
\text { aquatic }\end{array}$ & 116.6 & High: $\$ 3,000-7,000$ & $\begin{array}{l}\text { Almost real time locations transmitted } \\
\text { to satellites and sent to email, fax, web } \\
\text { or software }\end{array}$ & $\begin{array}{l}\text { GPS or other point } \\
\text { location }\end{array}$ & $250-1500 \mathrm{~m}$ & $\begin{array}{l}\text { months to }>1 \\
\text { year }\end{array}$ \\
\hline
\end{tabular}




\section{Supporting Information, Table S2. Key examples of international initiatives for biodiversity protection with implications for migratory}

species, and reciprocally, the impact of migratory connectivity research on the conservation potential of these initiatives.

\begin{tabular}{|c|c|c|c|c|}
\hline Threat & $\begin{array}{l}\text { Examples of } \\
\text { International } \\
\text { Initiatives } \\
\end{array}$ & Primary Policy Response & $\begin{array}{l}\text { Strengths and Weaknesses regarding conservation of } \\
\text { migratory species }\end{array}$ & $\begin{array}{l}\text { Impact of expanded } \\
\text { Migratory Connectivity research }\end{array}$ \\
\hline \multirow[t]{3}{*}{ Direct Overharvesting } & $\begin{array}{l}\text { International } \\
\text { Whaling Convention } \\
(1948)\end{array}$ & $\begin{array}{l}\text { Harvest limits and } \\
\text { moratorium }\end{array}$ & $\begin{array}{l}\text { Complete ban on commercial harvest; } \\
\text { Exceptions for "scientific research" exploited }\end{array}$ & Population monitoring improved \\
\hline & $\begin{array}{l}\text { US-Canada } \\
\text { Migratory Bird } \\
\text { Treaty }(1916)\end{array}$ & $\begin{array}{l}\text { Prohibited "take" of most } \\
\text { migratory birds }\end{array}$ & $\begin{array}{l}\text { Broad definition of "take"; Implemented by clear national laws } \\
\text { in US and Canada; enforcement is limited by resources }\end{array}$ & Population monitoring improved \\
\hline & $\begin{array}{l}\text { Convention on } \\
\text { International Trade in } \\
\text { Endangered Species } \\
(1987)\end{array}$ & $\begin{array}{l}\text { Restricts commercial trade } \\
\text { of listed threatened or } \\
\text { endangered species }\end{array}$ & $\begin{array}{l}\text { Strong ban on commercial trade with focus on enforcement; } \\
\text { Only covers species once they are threatened or endangered; No } \\
\text { coverage of habitat protection or domestic harvests }\end{array}$ & $\begin{array}{l}\text { Improved scientific basis for listing of } \\
\text { species; Improved population monitoring and } \\
\text { targeted enforcement }\end{array}$ \\
\hline \multirow[t]{6}{*}{ Habitat Loss } & $\begin{array}{l}\text { Convention on } \\
\text { Biological Diversity } \\
(1993)\end{array}$ & $\begin{array}{l}\text { Promotes inventories, } \\
\text { protected areas, and } \\
\text { conservation generally }\end{array}$ & $\begin{array}{l}\text { Comprehensive in highlighting all threats to biodiversity; } \\
\text { No enforcement mechanism; No specific focus on migration }\end{array}$ & $\begin{array}{l}\text { Scientific basis for taking action on a wide } \\
\text { range of species }\end{array}$ \\
\hline & $\begin{array}{l}\text { RAMSAR Wetlands } \\
\text { Convention (1975) }\end{array}$ & $\begin{array}{l}\text { Targets protection of } \\
\text { wetlands important to } \\
\text { migration }\end{array}$ & $\begin{array}{l}\text { Prioritizes protection of habitat areas for migration stop-overs; } \\
\text { Limited to wetlands }\end{array}$ & $\begin{array}{l}\text { Scientific basis for listing new wetlands and } \\
\text { for enhancing management of existing ones }\end{array}$ \\
\hline & $\begin{array}{l}\text { Convention on } \\
\text { Migratory Species } \\
(1983)\end{array}$ & $\begin{array}{l}\text { Targets conservation of } \\
\text { species in full range, } \\
\text { including migration }\end{array}$ & $\begin{array}{l}\text { Can include states throughout life cycle, including migration; } \\
\text { Limited participation; Limited species covered so far }\end{array}$ & $\begin{array}{l}\text { Identifying conservation priorities given } \\
\text { migration paths }\end{array}$ \\
\hline & $\begin{array}{l}\text { Inter-American Sea } \\
\text { Turtle Convention } \\
\text { (2001) }\end{array}$ & $\begin{array}{l}\text { Highlights need to protect } \\
\text { nesting habitat and to } \\
\text { reduce direct exploitation }\end{array}$ & $\begin{array}{l}\text { Has strengthened national commitments to protecting sea } \\
\text { turtles; limited protections while sea turtles at sea }\end{array}$ & $\begin{array}{l}\text { Improved scientific basis for protecting } \\
\text { animals outside of breeding areas }\end{array}$ \\
\hline & $\begin{array}{l}\text { UNESCO World } \\
\text { Heritage Convention } \\
(1975)\end{array}$ & $\begin{array}{l}\text { Gives international } \\
\text { attention to conservation of } \\
\text { listed sites }\end{array}$ & $\begin{array}{l}\text { Publicity of listing adds some protection; Limited number of } \\
\text { conservation-related sites }\end{array}$ & $\begin{array}{l}\text { Can build the scientific basis for listing sites; } \\
\text { Build international support for improved } \\
\text { management of sites }\end{array}$ \\
\hline & $\begin{array}{l}\text { Western-Hemisphere } \\
\text { Convention on } \\
\text { Nature Protection } \\
(1942)\end{array}$ & $\begin{array}{l}\text { Promotes national parks } \\
\text { and protected areas }\end{array}$ & $\begin{array}{l}\text { Highlights need to take measures for migratory birds } \\
\text { particularly; no enforcement or implementation infrastructure }\end{array}$ & $\begin{array}{l}\text { Increased attention might build support for } \\
\text { modernizing the convention }\end{array}$ \\
\hline $\begin{array}{l}\text { Chemicals and } \\
\text { pesticides }\end{array}$ & $\begin{array}{l}\text { Stockholm POPS } \\
\text { Convention (2004); }\end{array}$ & $\begin{array}{l}\text { Bans and regulates } \\
\text { pesticides and other } \\
\text { chemicals }\end{array}$ & $\begin{array}{l}\text { Complete bans on some of most damaging pesticides; Many } \\
\text { chemicals, such as neonicotinoids left to national law and often } \\
\text { unregulated }\end{array}$ & $\begin{array}{l}\text { Better understanding about the impacts of } \\
\text { neonicotinoids }\end{array}$ \\
\hline
\end{tabular}




\begin{tabular}{|c|c|c|c|c|}
\hline Invasive Species & $\begin{array}{l}\text { Biodiversity } \\
\text { Convention Invasive } \\
\text { Alien Species } \\
\text { Programme (2001) }\end{array}$ & $\begin{array}{l}\text { Provides voluntary } \\
\text { guidelines and some } \\
\text { financial and technical } \\
\text { support for controlling } \\
\text { invasive species }\end{array}$ & $\begin{array}{l}\text { Guidelines are voluntary and there is insufficient financial } \\
\text { support for effective implementation }\end{array}$ & $\begin{array}{l}\text { Better documentation on threats posed by } \\
\text { invasive species throughout life cycles could } \\
\text { attract more resources and political } \\
\text { commitment to controlling spread of invasive } \\
\text { species }\end{array}$ \\
\hline $\begin{array}{l}\text { Genetically Modified } \\
\text { Organisms (GMOs) }\end{array}$ & $\begin{array}{l}\text { Cartagena Biosafety } \\
\text { Protocol (2003) }\end{array}$ & $\begin{array}{l}\text { Control trade in GMOs by } \\
\text { implementing a system of } \\
\text { informed consent }\end{array}$ & $\begin{array}{l}\text { Creates a labelling and information exchange system; } \\
\text { Regulation left to national levels }\end{array}$ & $\begin{array}{l}\text { Studies could close gaps in knowledge about } \\
\text { potential impacts and provide the scientific } \\
\text { basis for regulating certain GMOs }\end{array}$ \\
\hline \multirow[t]{2}{*}{ Climate Change } & $\begin{array}{l}\text { UN Framework } \\
\text { Convention on } \\
\text { Climate Change } \\
\text { (1994) and Paris } \\
\text { agreement (2016) }\end{array}$ & $\begin{array}{l}\text { UNFCCC Creates the } \\
\text { framework for addressing } \\
\text { climate change; Paris } \\
\text { Agreement signals long-term } \\
\text { switch from fossil fuel use } \\
\text { and has prompted nationally } \\
\text { determined commitments }\end{array}$ & $\begin{array}{l}\text { Almost all countries are now participating; Ambition gap is still } \\
\text { significant between promises and levels needed to avoid severe } \\
\text { impacts; some unanticipated consequences from climate policy } \\
\text { (e.g., land conversion due to biofuels) }\end{array}$ & $\begin{array}{l}\text { Helps prioritize and build support for where } \\
\text { we put climate finance, May also help } \\
\text { mobilize people in these areas }\end{array}$ \\
\hline & $\begin{array}{l}\text { Reduced Emissions } \\
\text { from Deforestation } \\
\text { and Degradation } \\
\text { (REDD) (2009) }\end{array}$ & $\begin{array}{l}\text { Provide incentives to } \\
\text { conserve forests as carbon } \\
\text { sinks under the climate } \\
\text { regime }\end{array}$ & $\begin{array}{l}\text { Links climate mitigation with forest conservation; } \\
\text { Less international financial support than expected }\end{array}$ & $\begin{array}{l}\text { Helps prioritize sites with wildlife co- } \\
\text { benefits }\end{array}$ \\
\hline $\begin{array}{l}\text { Macroeconomic } \\
\text { growth (trade, } \\
\text { investment, finance) }\end{array}$ & $\begin{array}{l}\text { Peru-US Free Trade } \\
\text { Agreement (2009) } \\
\text { EU Forest law } \\
\text { Enforcement, } \\
\text { Governance and Trade } \\
\text { (FLEGT) Action plan } \\
\text { (2003)FLEGT } \\
\text { Agreements }\end{array}$ & $\begin{array}{l}\text { Agreements to strengthen } \\
\text { sustainable forest } \\
\text { management in context of } \\
\text { trade agreements }\end{array}$ & $\begin{array}{l}\text { Linking forestry standards to trade agreements can build } \\
\text { political will and line up legal trade in forests with sustainability } \\
\text { goals. Limited to key natural resource and commodity sectors } \\
\text { (e.g., forest conservation in Peru); may have limited impact on } \\
\text { the ground }\end{array}$ & $\begin{array}{l}\text { Could build basis for side agreements for } \\
\text { increased cooperation in protecting shared } \\
\text { resources }\end{array}$ \\
\hline $\begin{array}{l}\text { Unsustainable } \\
\text { Consumption Patterns }\end{array}$ & $\begin{array}{l}\text { Global Supply Chain } \\
\text { Sectoral Standards } \\
\text { (E.g., FSC, MSC, bird- } \\
\text { friendly coffee, RSPO) }\end{array}$ & $\begin{array}{l}\text { Sets standards for } \\
\text { certifications, eco-labels, } \\
\text { green finance, etc. }\end{array}$ & $\begin{array}{l}\text { Many initiatives in many sectors, often with a focus on reducing } \\
\text { land conversion; Most are voluntary and with limited } \\
\text { penetration into the market; sometimes weak scientific basis for } \\
\text { standards }\end{array}$ & Improves Scientific basis for standards \\
\hline
\end{tabular}

